\title{
The WSES: what do we see in the future?
}

\author{
Belinda De Simone ${ }^{1 *}$ (D) , Yoram Kluger ${ }^{2}$, Ernest E. Moore ${ }^{3}$, Salomone Di Saverio ${ }^{4}$, Massimo Sartelli ${ }^{5}$, Luca Ansaloni ${ }^{6}$, \\ Federico Coccolini ${ }^{7}$, Walter L. Biffl ${ }^{8}$ and Fausto Catena ${ }^{9}$
}

\begin{abstract}
We present the New Year letter from the WSES board to wish everyone a new year full of positive surprises and good news, despite COVID-19 pandemic.

We confirm the WSES primary aim: to promote education in emergency surgery putting together all the world experts on emergency surgery without restrictions or boundaries, in inclusivity, equality, and equal opportunities. This will be the year of innovations and WSES will assess the application of artificial intelligence technologies in emergency and trauma surgery.

Thank you All for trusting us with your collaboration.
\end{abstract}

Keywords: Emergency surgery, WSES, Program, Inclusivity, Equality, Education, WJES, Artificial intelligence

\section{Main text}

The year that just passed over was challenging.

The WSES was founded in 2007 to represent not another scientific society designed to give visibility to certain people or to compete with other societies or associations with an annual Congress, but to promote education in emergency surgery [1].

At the WSES Bergamo Congress in 2013, the WSESWJES board established the Scientific Development Policy for the Society and Journal: the project was based on the idea to create an organized scientific movement having the objective to standardize the state of the art for emergency surgery while attempting to develop guidelines for related topics and promoting original research [2].

In these years, the society matured, including members from all over the world and the WJES reached an IF of 4.1. The WSES is the only international society to have conceived and developed the Congress Impact Factor to assess the scientific quality of local and international conventions to help physicians and surgeons in choosing the most appropriate conference, meeting or congress [3].

\footnotetext{
* Correspondence: desimone.belinda@gmail.com

'Department of General, Emergency and Metabolic Minimally Invasive Surgery, Poissy and Saint Germain en Laye Hospitals, 10 rue du Champ Gaillard, 78300 Poissy, France

Full list of author information is available at the end of the article
}

The WSES-WJES Educational Team organized international courses, published Trauma Surgery and Acute Care (non-trauma) books to promulgate emergency surgery education around the world, by using WSES-WJES guidelines.

High impact guidelines about hot topics in emergency surgery were conceived and published and now they represent an important tool to define the good clinical practice.

All these goals result from a friendly and inclusive collaboration among high expertise academic and hospital trauma and acute care surgeons of all nationality with no restrictions or boundaries.

The year 2020 that just passed over was challenging for all of us; we faced COVID-19 pandemic that has changed our vision of practice and life.

Every one of us such as surgeon and human being experienced isolation from beloved family and friends and empathy for all the healthcare professionals and people that died because SARS-CoV-2, but this did not demotivate WSES board members.

The first WSES Congress web has been held in November 2020.

We realized the importance of technologies in modern surgical education and practice, to shorten distances and go on with scientific activity and surgical education, inspiring young emergency surgeons. 
This era of surgical education is characterized by rapid and dynamic changes in knowledge, understanding of the surgical disease, new procedures, and technologies to artificial intelligence.

The time is right to be social and progress in communication and diffusion of guidelines by:

- A YouTube channel to show new techniques and devices in trauma and emergency surgery;

- The WSES Academy webinars project.

Our main aims are again inclusion, equality and equal opportunities, involving as much as possible professionals working in different countries and continents to provide common tools to identify the best clinical practice.

We are probably the "last of the Mohicans"; a sort of special force of general surgery, selected and to be preserved, but we are not few and we claim the importance of emergency surgery [4].

This is a new start, a new beginning.

Happy New Year!

\section{Conclusion}

This is the New Year letter from WSES board to wish everyone a new year full of positive surprises and good news, despite COVID-19 pandemic.

With a glance to the past experiences and goals fulfilled, we want to repeat that our primary objective is promoting education in emergency surgery in inclusivity, equality, and equal opportunities.

For the future, we plan to be more social, dynamic, and modern in communication and sharing our scientific activity.

This is a new start, a new beginning.

\section{Abbreviations}

WSES: World Society of Emergency Surgery; WJES: World Journal of

Emergency Surgery

\section{Acknowledgements}

Not applicable

\section{Authors' contributions}

BDS conceived and wrote the paper. FC approved and revised the paper. All the authors read and approved the final paper.

\section{Funding}

Not applicable

Availability of data and materials

Not applicable

\section{Declarations}

Ethics approval and consent to participate

Not applicable

\section{Consent for publication}

Not applicable

\section{Competing interests}

The authors declare that they have no competing interests for this article.

\section{Author details}

${ }^{1}$ Department of General, Emergency and Metabolic Minimally Invasive Surgery, Poissy and Saint Germain en Laye Hospitals, 10 rue du Champ Gaillard, 78300 Poissy, France. ${ }^{2}$ Department of Emergency and Trauma Surgery, Rambam Health Campus, Haifa, Israel. ${ }^{3}$ Shock Trauma Center at Denver Health, Denver, CO, USA. ${ }^{4}$ Department of General Surgery, University Hospital of Varese, University of Insubria, Varese, Italy. ${ }^{5}$ Department of General Surgery, Macerata Hospital, Macerata, Italy. ${ }^{6}$ Department of General Surgery, University Hospital of Pavia, Pavia, Italy. 'Department of Trauma and Emergency Surgery, University Hospital of Pisa, Pisa, Italy. ${ }^{8}$ Department of Trauma and Acute Care Surgery, Scripps Memorial Hospital, La Jolla, CA, USA. ${ }^{9}$ Department of Emergency and Trauma Surgery, University Hospital of Parma, Parma, Italy.

Received: 28 January 2021 Accepted: 2 March 2021

Published online: 20 March 2021

\section{References}

1. Catena F, Moore EE. World Journal of Emergency Surgery (WJES), World Society of Emergency Surgery (WSES) and the role of emergency surgery in the world. World J Emerg Surg. 2007;2:3. https://doi.org/10.1186/17497922-2-3. Published 2007 Feb 8.

2. Catena F, Moore EE, Ansaloni L, et al. Emergency surgeon: "last of the Mohicans" 2014-2016 editorial policy WSES- WJES: position papers, guidelines, courses, books and original research; from WJES impact factor to WSES congress impact factor. World J Emerg Surg. 2014;9(1):14. https://doi. org/10.1186/1749-7922-9-14. Published 2014 Feb 3.

3. De Simone B, Ansaloni L, Kelly MD, et al. The Congress Impact Factor: A proposal from board members of the World Society of Emergency Surgeons.it (WSES) and Academy of Emergency Medicine and Care (AcEMC) [version 2; peer review: 2 approved]. F1000Research. 2018;7:1185. https://doi org/10.12688/f1000research.15429.2

4. Catena F, Biffl W, De Simone B, Sartelli M, Di Saverio S, Kluger Y, Moore EE, Ansaloni L, Coccolini F. Emergency general surgeons: the special forces of general surgery (the "navy seals paradigm"). World J Emerg Surg. 2020;15(1).

\section{Publisher's Note}

Springer Nature remains neutral with regard to jurisdictional claims in published maps and institutional affiliations.

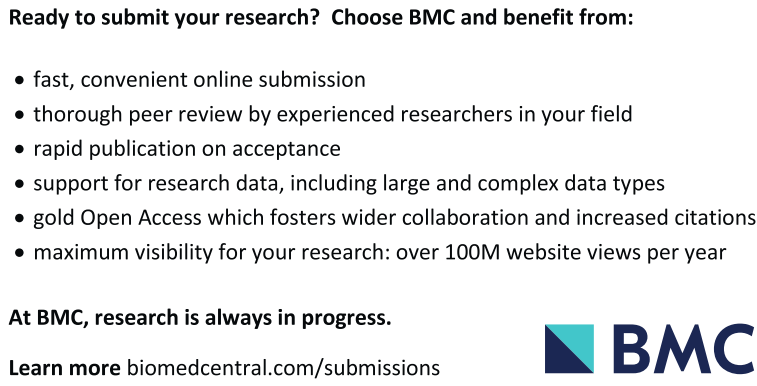

Ready to submit your research? Choose BMC and benefit from:

- fast, convenient online submission

- thorough peer review by experienced researchers in your field

- rapid publication on acceptance

- support for research data, including large and complex data types

- gold Open Access which fosters wider collaboration and increased citations

- maximum visibility for your research: over $100 \mathrm{M}$ website views per year

At BMC, research is always in progress.

Learn more biomedcentral.com/submissions 